\title{
Stephen Jay Gould
}

\section{Nonoverlapping Magisteria *}

Incongruous places often inspire anomalous stories. In early 1984, I spent several nights at the Vatican housed in a hotel built for itinerant priests. While pondering over such puzzling issues as the intended function of the bidets in each bathroom, and hungering for something other than plum jam on my breakfast rolls (why did the basket only contain hundreds of identical plum packets and not a one of, say, strawberry?), I encountered yet another among the innumerable issues of contrasting cultures that can make life so interesting. Our crowd (present in Rome for a meeting on nuclear winter sponsored by the Pontifical Academy of Sciences) shared the hotel with a group of French and Italian Jesuit priests who were also professional scientists.

At lunch, the priests called me over to their table to pose a problem that had been troubling them. What, they wanted to know, was going on in America with all this talk about "scientific creationism"? One asked me: "Is evolution really in some kind of trouble, and if so, what could such trouble be? I have always been taught that no doctrinal conflict exists between evolution and Catholic faith, and the evidence for evolution seems both entirely satisfactory and utterly overwhelming. Have I missed something?"

A lively pastiche of French, Italian, and English conversation then ensued for half an hour or so, but the priests all seemed reassured by my general answer: Evolution has encountered no intellectual trouble; no new arguments have been offered. Creationism is a homegrown phenomenon of American sociocul-

\footnotetext{
"The article is reprinted from: Stephen Jay Gould, "Nonoverlapping Magisteria", Natural History 1997, vol. 106, pp. 16-22. The article is reprinted by permission of the Editorial Board.
} 
tural history - a splinter movement (unfortunately rather more of a beam these days) of Protestant fundamentalists who believe that every word of the Bible must be literally true, whatever such a claim might mean. We all left satisfied, but I certainly felt bemused by the anomaly of my role as a Jewish agnostic, trying to reassure a group of Catholic priests that evolution remained both true and entirely consistent with religious belief.

Another story in the same mold: I am often asked whether I ever encounter creationism as a live issue among my Harvard undergraduate students. I reply that only once, in nearly thirty years of teaching, did I experience such an incident. A very sincere and serious freshman student came to my office hours with the following question that had clearly been troubling him deeply: "I am a devout Christian and have never had any reason to doubt evolution, an idea that seems both exciting and particularly well documented. But my roommate, a proselytizing Evangelical, has been insisting with enormous vigor that I cannot be both a real Christian and an evolutionist. So tell me, can a person believe both in God and evolution?" Again, I gulped hard, did my intellectual duty, and reassured him that evolution was both true and entirely compatible with Christian belief - a position I hold sincerely, but still an odd situation for a Jewish agnostic.

These two stories illustrate a cardinal point, frequently unrecognized but absolutely central to any understanding of the status and impact of the politically potent, fundamentalist doctrine known by its self-proclaimed oxymoron as "scientific creationism" - the claim that the Bible is literally true, that all organisms were created during six days of twenty-four hours, that the earth is only a few thousand years old, and that evolution must therefore be false. Creationism does not pit science against religion (as my opening stories indicate), for no such conflict exists. Creationism does not raise any unsettled intellectual issues about the nature of biology or the history of life. Creationism is a local and parochial movement, powerful only in the United States among Western nations, and prevalent only among the few sectors of American Protestantism that choose to read the Bible as an inerrant document, literally true in every jot and tittle. 
I do not doubt that one could find an occasional nun who would prefer to teach creationism in her parochial school biology class or an occasional orthodox rabbi who does the same in his yeshiva, but creationism based on biblical literalism makes little sense in either Catholicism or Judaism for neither religion maintains any extensive tradition for reading the Bible as literal truth rather than illuminating literature, based partly on metaphor and allegory (essential components of all good writing) and demanding interpretation for proper understanding. Most Protestant groups, of course, take the same position - the fundamentalist fringe notwithstanding.

The position that I have just outlined by personal stories and general statements represents the standard attitude of all major Western religions (and of Western science) today. (I cannot, through ignorance, speak of Eastern religions, although I suspect that the same position would prevail in most cases.) The lack of conflict between science and religion arises from a lack of overlap between their respective domains of professional expertise - science in the empirical constitution of the universe, and religion in the search for proper ethical values and the spiritual meaning of our lives. The attainment of wisdom in a full life requires extensive attention to both domains - for a great book tells us that the truth can make us free and that we will live in optimal harmony with our fellows when we learn to do justly, love mercy, and walk humbly.

In the context of this standard position, I was enormously puzzled by a statement issued by Pope John Paul II on October 22, 1996, to the Pontifical Academy of Sciences, the same body that had sponsored my earlier trip ${ }^{1}$ to the Vatican. In this document, entitled "Truth Cannot Contradict Truth", ${ }^{2}$ the pope defended both the evidence for evolution and the consistency of the theory with Catholic religious doctrine. Newspapers throughout the world responded with front-page headlines, as in the New York Times for October 25:

"Pope Bolsters Church's Support for Scientific View of Evolution"

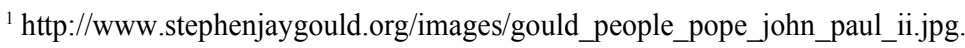

${ }^{2}$ http://www.newadvent.org/library/docs_jp02tc.htm.
} 
Now I know about "slow news days" and I do admit that nothing else was strongly competing for headlines at that particular moment. (The Times could muster nothing more exciting for a lead story than Ross Perot's refusal to take Bob Dole's advice and quit the presidential race.) Still, I couldn't help feeling immensely puzzled by all the attention paid to the pope's statement (while being wryly pleased, of course, for we need all the good press we can get, especially from respected outside sources). The Catholic Church had never opposed evolution and had no reason to do so. Why had the pope issued such a statement at all? And why had the press responded with an orgy of worldwide, front-page coverage?

I could only conclude at first, and wrongly as I soon learned, that journalists throughout the world must deeply misunderstand the relationship between science and religion, and must therefore be elevating a minor papal comment to unwarranted notice. Perhaps most people really do think that a war exists between science and religion, and that (to cite a particularly newsworthy case) evolution must be intrinsically opposed to Christianity. In such a context, a papal admission of evolution's legitimate status might be regarded as major news indeed a sort of modern equivalent for a story that never happened, but would have made the biggest journalistic splash of 1640: Pope Urban VIII releases his most famous prisoner from house arrest and humbly apologizes, "Sorry, Signor Galileo [...] the sun, er, is central".

But I then discovered that the prominent coverage of papal satisfaction with evolution had not been an error of non-Catholic Anglophone journalists. The Vatican itself had issued the statement as a major news release. And Italian newspapers had featured, if anything, even bigger headlines and longer stories. The conservative Il Giornale, for example, shouted from its masthead: "Pope Says We May Descend from Monkeys".

Clearly, I was out to lunch. Something novel or surprising must lurk within the papal statement but what could it be? - especially given the accuracy of my primary impression (as I later verified) that the Catholic Church values scientific study, views science as no threat to religion in general or Catholic doctrine in particular, and has long accepted both the legitimacy of evolution as a field of study and the potential harmony of evolutionary conclusions with Catholic faith. 
As a former constituent of Tip O'Neill's, I certainly know that "all politics is local" - and that the Vatican undoubtedly has its own internal reasons, quite opaque to me, for announcing papal support of evolution in a major statement. Still, I knew that I was missing some important key, and I felt frustrated. I then remembered the primary rule of intellectual life: when puzzled, it never hurts to read the primary documents - a rather simple and self-evident principle that has, nonetheless, completely disappeared from large sectors of the American experience.

I knew that Pope Pius XII (not one of my favorite figures in twentieth-century history, to say the least) had made the primary statement in a 1950 encyclical entitled Humani Generis. ${ }^{3}$ I knew the main thrust of his message: Catholics could believe whatever science determined about the evolution of the human body, so long as they accepted that, at some time of his choosing, God had infused the soul into such a creature. I also knew that I had no problem with this statement, for whatever my private beliefs about souls, science cannot touch such a subject and therefore cannot be threatened by any theological position on such a legitimately and intrinsically religious issue. Pope Pius XII, in other words, had properly acknowledged and respected the separate domains of science and theology. Thus, I found myself in total agreement with Humani Generis - but I had never read the document in full (not much of an impediment to stating an opinion these days).

I quickly got the relevant writings from, of all places, the Internet. (The pope is prominently on-line, but a Luddite like me is not. So I got a computerliterate associate to dredge up the documents. I do love the fracture of stereotypes implied by finding religion so hep and a scientist so square.) Having now read in full both Pope Pius's Humani Generis of 1950 and Pope John Paul's proclamation of October 1996, I finally understand why the recent statement seems so new, revealing, and worthy of all those headlines. And the message could not be more welcome for evolutionists and friends of both science and religion.

\footnotetext{
${ }^{3} \mathrm{http} / / /$ www.newadvent.org/library/docs pi12hg.htm.
} 
The text of Humani Generis focuses on the magisterium (or teaching authority) of the Church - a word derived not from any concept of majesty or awe but from the different notion of teaching, for magister is Latin for "teacher". We may, I think, adopt this word and concept to express the central point of this essay and the principled resolution of supposed "conflict" or "warfare" between science and religion. No such conflict should exist because each subject has a legitimate magisterium, or domain of teaching authority — and these magisteria do not overlap (the principle that I would like to designate as NOMA, or "nonoverlapping magisteria").

The net of science covers the empirical universe: what is it made of (fact) and why does it work this way (theory). The net of religion extends over questions of moral meaning and value. These two magisteria do not overlap, nor do they encompass all inquiry (consider, for starters, the magisterium of art and the meaning of beauty). To cite the arch cliches, we get the age of rocks, and religion retains the rock of ages; we study how the heavens go, and they determine how to go to heaven.

This resolution might remain all neat and clean if the nonoverlapping magisteria (NOMA) of science and religion were separated by an extensive no man's land. But, in fact, the two magisteria bump right up against each other, interdigitating in wondrously complex ways along their joint border. Many of our deepest questions call upon aspects of both for different parts of a full answer - and the sorting of legitimate domains can become quite complex and difficult. To cite just two broad questions involving both evolutionary facts and moral arguments: Since evolution made us the only earthly creatures with advanced consciousness, what responsibilities are so entailed for our relations with other species? What do our genealogical ties with other organisms imply about the meaning of human life?

Pius XII's Humani Generis is a highly traditionalist document by a deeply conservative man forced to face all the "isms" and cynicisms that rode the wake of World War II and informed the struggle to rebuild human decency from the ashes of the Holocaust. The encyclical, subtitled "Concerning some false opinions which threaten to undermine the foundations of Catholic doctrine" begins with a statement of embattlement: 
Disagreement and error among men on moral and religious matters have always been a cause of profound sorrow to all good men, but above all to the true and loyal sons of the Church, especially today, when we see the principles of Christian culture being attacked on all sides.

Pius lashes out, in turn, at various external enemies of the Church: pantheism, existentialism, dialectical materialism, historicism. and of course and preeminently, communism. He then notes with sadness that some well-meaning folks within the Church have fallen into a dangerous relativism - "a theological pacifism and egalitarianism, in which all points of view become equally valid" - in order to include people of wavering faith who yearn for the embrace of Christian religion but do not wish to accept the particularly Catholic magisterium.

What is this world coming to when these noxious novelties can so discombobulate a revealed and established order? Speaking as a conservative's conservative, Pius laments:

Novelties of this kind have already borne their deadly fruit in almost all branches of theology. [...] Some question whether angels are personal beings, and whether matter and spirit differ essentially. [...] Some even say that the doctrine of Transubstantiation, based on an antiquated philosophic notion of substance, should be so modified that the Real Presence of Christ in the Holy Eucharist be reduced to a kind of symbolism.

Pius first mentions evolution to decry a misuse by overextension often promulgated by zealous supporters of the anathematized "isms":

Some imprudently and indiscreetly hold that evolution [...] explains the origin of all things. [...] Communists gladly subscribe to this opinion so that, when the souls of men have been deprived of every idea of a personal God, they may the more efficaciously defend and propagate their dialectical materialism.

Pius's major statement on evolution occurs near the end of the encyclical in paragraphs 35 through 37 . He accepts the standard model of NOMA and begins by acknowledging that evolution lies in a difficult area where the domains press hard against each other. "It remains for US now to speak about those questions which, although they pertain to the positive sciences, are nevertheless more or less connected with the truths of the Christian faith". (Interestingly, the main 
thrust of these paragraphs does not address evolution in general but lies in refuting a doctrine that Pius calls "polygenism", or the notion of human ancestry from multiple parents - for he regards such an idea as incompatible with the doctrine of original sin, "which proceeds from a sin actually committed by an individual Adam and which, through generation, is passed on to all and is in everyone as his own". In this one instance, Pius may be transgressing the NOMA principle - but I cannot judge, for I do not understand the details of Catholic theology and therefore do not know how symbolically such a statement may be read. If Pius is arguing that we cannot entertain a theory about derivation of all modern humans from an ancestral population rather than through an ancestral individual (a potential fact) because such an idea would question the doctrine of original sin (a theological construct), then I would declare him out of line for letting the magisterium of religion dictate a conclusion within the magisterium of science.)

Pius then writes the well-known words that permit Catholics to entertain the evolution of the human body (a factual issue under the magisterium of science), so long as they accept the divine Creation and infusion of the soul (a theological notion under the magisterium of religion):

The Teaching Authority of the Church does not forbid that, in conformity with the present state of human sciences and sacred theology, research and discussions, on the part of men experienced in both fields, take place with regard to the doctrine of evolution, in as far as it inquires into the origin of the human body as coming from pre-existent and living matter - for the Catholic faith obliges us to hold that souls are immediately created by God.

I had, up to here, found nothing surprising in Humani Generis, and nothing to relieve my puzzlement about the novelty of Pope John Paul's recent statement. ${ }^{4}$ But I read further and realized that Pope Pius had said more about evolution, something I had never seen quoted, and that made John Paul's statement most interesting indeed. In short, Pius forcefully proclaimed that while evolution may be legitimate in principle, the theory, in fact, had not been proven and might well be entirely wrong. One gets the strong impression, moreover, that

\footnotetext{
${ }^{4}$ http://www.firstthings.com/article/1997/03/004-theories-of-evolution.
} 
Pius was rooting pretty hard for a verdict of falsity. Continuing directly from the last quotation, Pius advises us about the proper study of evolution:

However, this must be done in such a way that the reasons for both opinions, that is, those favorable and those unfavorable to evolution, be weighed and judged with the necessary seriousness, moderation and measure. [...] Some, however, rashly transgress this liberty of discussion, when they act as if the origin of the human body from preexisting and living matter were already completely certain and proved by the facts which have been discovered up to now and by reasoning on those facts, and as if there were nothing in the sources of divine revelation which demands the greatest moderation and caution in this question.

To summarize, Pius generally accepts the NOMA principle of nonoverlapping magisteria in permitting Catholics to entertain the hypothesis of evolution for the human body so long as they accept the divine infusion of the soul. But he then offers some (holy) fatherly advice to scientists about the status of evolution as a scientific concept: the idea is not yet proven, and you all need to be especially cautious because evolution raises many troubling issues right on the border of my magisterium. One may read this second theme in two different ways: either as a gratuitous incursion into a different magisterium or as a helpful perspective from an intelligent and concerned outsider. As a man of good will, and in the interest of conciliation, I am happy to embrace the latter reading.

In any case, this rarely quoted second claim (that evolution remains both unproven and a bit dangerous) - and not the familiar first argument for the NOMA principle (that Catholics may accept the evolution of the body so long as they embrace the creation of the soul) - defines the novelty and the interest of John Paul's recent statement.

John Paul begins by summarizing Pius's older encyclical of 1950, and particularly by reaffirming the NOMA principle - nothing new here, and no cause for extended publicity:

In his encyclical Humani Generis (1950), my predecessor Pius XII had already stated that there was no opposition between evolution and the doctrine of the faith about man and his vocation. 
To emphasize the power of NOMA, John Paul poses a potential problem and a sound resolution: How can we reconcile science's claim for physical continuity in human evolution with Catholicism's insistence that the soul must enter at a moment of divine infusion:

With man, then, we find ourselves in the presence of an ontological difference, an ontological leap, one could say. However, does not the posing of such ontological discontinuity run counter to that physical continuity which seems to be the main thread of research into evolution in the field of physics and chemistry? Consideration of the method used in the various branches of knowledge makes it possible to reconcile two points of view which would seem irreconcilable. The sciences of observation describe and measure the multiple manifestations of life with increasing precision and correlate them with the time line. The moment of transition to the spiritual cannot be the object of this kind of observation.

The novelty and news value of John Paul's statement lies, rather, in his profound revision of Pius's second and rarely quoted claim that evolution, while conceivable in principle and reconcilable with religion, can cite little persuasive evidence, and may well be false. John Paul - states and I can only say amen, and thanks for noticing - that the half century between Pius's surveying the ruins of World War II and his own pontificate heralding the dawn of a new millennium has witnessed such a growth of data, and such a refinement of theory, that evolution can no longer be doubted by people of good will:

Pius XII added [...] that this opinion [evolution] should not be adopted as though it were a certain, proven doctrine. [...] Today, almost half a century after the publication of the encyclical, new knowledge has led to the recognition of more than one hypothesis in the theory of evolution. It is indeed remarkable that this theory has been progressively accepted by researchers, following a series of discoveries in various fields of knowledge. The convergence, neither sought nor fabricated, of the results of work that was conducted independently is in itself a significant argument in favor of the theory.

In conclusion, Pius had grudgingly admitted evolution as a legitimate hypothesis that he regarded as only tentatively supported and potentially (as I suspect he hoped) untrue. John Paul, nearly fifty years later, reaffirms the legitimacy of evolution under the NOMA principle - no news here - but then adds that additional data and theory have placed the factuality of evolution beyond 
reasonable doubt. Sincere Christians must now accept evolution not merely as a plausible possibility but also as an effectively proven fact. In other words, official Catholic opinion on evolution has moved from "say it ain't so, but we can deal with it if we have to" (Pius's grudging view of 1950) to John Paul's entirely welcoming "it has been proven true; we always celebrate nature's factuality, and we look forward to interesting discussions of theological implications". I happily endorse this turn of events as gospel - literally "good news". I may represent the magisterium of science, but I welcome the support of a primary leader from the other major magisterium of our complex lives. And I recall the wisdom of King Solomon: "As cold waters to a thirsty soul, so is good news from a far country" (Prov. 25:25).

Just as religion must bear the cross of its hard-liners. I have some scientific colleagues, including a few prominent enough to wield influence by their writings, who view this rapprochement of the separate magisteria with dismay. To colleagues like me - agnostic scientists who welcome and celebrate the rapprochement, especially the pope's latest statement - they say: "C'mon, be honest; you know that religion is addle-pated, superstitious, old-fashioned b.s.; you're only making those welcoming noises because religion is so powerful, and we need to be diplomatic in order to assure public support and funding for science". I do not think that this attitude is common among scientists, but such a position fills me with dismay - and I therefore end this essay with a personal statement about religion, as a testimony to what I regard as a virtual consensus among thoughtful scientists (who support the NOMA principle as firmly as the pope does).

I am not, personally, a believer or a religious man in any sense of institutional commitment or practice. But I have enormous respect for religion, and the subject has always fascinated me, beyond almost all others (with a few exceptions, like evolution, paleontology, and baseball). Much of this fascination lies in the historical paradox that throughout Western history organized religion has fostered both the most unspeakable horrors and the most heart-rending examples of human goodness in the face of personal danger. (The evil, I believe, lies in the occasional confluence of religion with secular power. The Catholic Church has sponsored its share of horrors, from Inquisitions to liquidations - but only because this institution held such secular power during so much of Western his- 
tory. When my folks held similar power more briefly in Old Testament times, they committed just as many atrocities with many of the same rationales.)

I believe, with all my heart, in a respectful, even loving concordat between our magisteria - the NOMA solution. NOMA represents a principled position on moral and intellectual grounds, not a mere diplomatic stance. NOMA also cuts both ways. If religion can no longer dictate the nature of factual conclusions properly under the magisterium of science, then scientists cannot claim higher insight into moral truth from any superior knowledge of the world's empirical constitution. This mutual humility has important practical consequences in a world of such diverse passions.

Religion is too important to too many people for any dismissal or denigration of the comfort still sought by many folks from theology. I may, for example, privately suspect that papal insistence on divine infusion of the soul represents a sop to our fears, a device for maintaining a belief in human superiority within an evolutionary world offering no privileged position to any creature. But I also know that souls represent a subject outside the magisterium of science. My world cannot prove or disprove such a notion, and the concept of souls cannot threaten or impact my domain. Moreover, while I cannot personally accept the Catholic view of souls, I surely honor the metaphorical value of such a concept both for grounding moral discussion and for expressing what we most value about human potentiality: our decency, care, and all the ethical and intellectual struggles that the evolution of consciousness imposed upon us.

As a moral position (and therefore not as a deduction from my knowledge of nature's factuality), I prefer the "cold bath" theory that nature can be truly "cruel" and "indifferent" — in the utterly inappropriate terms of our ethical discourse - because nature was not constructed as our eventual abode, didn't know we were coming (we are, after all, interlopers of the latest geological microsecond), and doesn't give a damn about us (speaking metaphorically). I regard such a position as liberating, not depressing, because we then become free to conduct moral discourse - and nothing could be more important - in our own terms, spared from the delusion that we might read moral truth passively from nature's factuality. 
But I recognize that such a position frightens many people, and that a more spiritual view of nature retains broad appeal (acknowledging the factuality of evolution and other phenomena, but still seeking some intrinsic meaning in human terms, and from the magisterium of religion). I do appreciate, for example, the struggles of a man who wrote to the New York Times on November 3, 1996, to state both his pain and his endorsement of John Paul's statement:

Pope John Paul II's acceptance of evolution touches the doubt in my heart. The problem of pain and suffering in a world created by a God who is all love and light is hard enough to bear, even if one is a creationist. But at least a creationist can say that the original creation, coming from the hand of God was good, harmonious, innocent and gentle. What can one say about evolution, even a spiritual theory of evolution? Pain and suffering, mindless cruelty and terror are its means of creation. Evolution's engine is the grinding of predatory teeth upon the screaming, living flesh and bones of prey. [...] If evolution be true, my faith has rougher seas to sail.

I don't agree with this man, but we could have a wonderful argument. I would push the "cold bath" theory: he would (presumably) advocate the theme of inherent spiritual meaning in nature, however opaque the signal. But we would both be enlightened and filled with better understanding of these deep and ultimately unanswerable issues. Here, I believe, lies the greatest strength and necessity of NOMA, the nonoverlapping magisteria of science and religion. NOMA permits - indeed enjoins - the prospect of respectful discourse, of constant input from both magisteria toward the common goal of wisdom. If human beings are anything special, we are the creatures that must ponder and talk. Pope John Paul II would surely point out to me that his magisterium has always recognized this distinction, for "in principio, erat verbum" - "In the beginning was the Word".

\section{Postscript}

Carl Sagan ${ }^{5}$ organized and attended the Vatican meeting that introduces this essay; he also shared my concern for fruitful cooperation between the different but vital realms of science and religion. Carl was also one of my dearest friends.

\footnotetext{
${ }^{5}$ http://www.stephenjaygould.org/library/gould_carlsagan.html.
} 
I learned of his untimely death on the same day that I read the proofs for this essay. I could only recall Nehru's observations on Gandhi's death - that the light had gone out, and darkness reigned everywhere. But I then contemplated what Carl had done in his short sixty-two years and remembered John Dryden's ode for Henry Purcell, a great musician who died even younger: "He long ere this had tuned the jarring spheres, and left no hell below".

The days I spent with Carl in Rome were the best of our friendship. We delighted in walking around the Eternal City, feasting on its history and architecture - and its food! Carl took special delight in the anonymity that he still enjoyed in a nation that had not yet aired Cosmos, the greatest media work in popular science of all time.

I dedicate this essay to his memory. Carl also shared my personal suspicion about the nonexistence of souls — but I cannot think of a better reason for hoping we are wrong than the prospect of spending eternity roaming the cosmos in friendship and conversation with this wonderful soul.

Stephen Jay Gould

\section{Nonoverlapping Magisteria}

\section{Summary}

There is no conflict between science and religion. Creationism is only a local movement, prevalent only among the few sectors of American Protestantism that read the Bible as an inerrant, literally true document. Creationism based on biblical literalism makes little sense in either Catholicism or Judaism, for neither religion maintains any extensive tradition for reading the Bible as literal truth. The lack of conflict arises from a lack of overlap between the respective domains of professional expertise of science and religion. No conflict should exist because the magisteria of science and religion do not overlap. According to the principle of NOMA — "nonoverlapping magisteria" - science covers the empirical universe, while religion covers questions of moral meaning and ethical value. This principle was obeyed by both Pius XII and John Paul II. They both saw no conflict between Catholic faith and a theory of evolution. However, there is one important difference between their positions. Pius XII admitted evolution as a legitimate hypothesis, but at the same time he proclaimed that the theory of evolution had not been proven and might well be wrong. On the other hand, John Paul II stated that evolution can no longer be doubted. Now, he stated, evolution must be accepted not merely as a plausible possibility but also as an effectively 
proven fact. This fact is no threat to religion if one accepts the principle of NOMA. As a consequence of this principle, religion can no longer dictate the factual conclusions that belong to the magisterium of science, nor may scientists decide on moral truths.

Keywords: NOMA, Humani generis, Pius XII, John Paul II, science and religion, creation and evolution, Catholic Church and evolution. 